logos_i_ethos_2014_1_(36), s.111-128

Marcin Subczak

\title{
Od „tragicznego" do "terapeutycznego" wymiaru filozoficznego etosu. Koncepcja filozofii w De consolatione Boecjusza
}

Boecjusz (Anicius Manlius Torquatus Severinus) należy do grona najbardziej znaczących postaci przełomu epok ${ }^{1}$. Jego dorobek - jak to określa Frederick Copleston - był jedną z dróg (obok pism PseudoMarcin Subczak - asystent w Zakładzie Historii Filozofii na Wydziale Socjologiczno-Historycznym Uniwersytetu Rzeszowskiego. Zainteresowania: historia filozofii antycznej, Platonizm i jego recepcja, historia filozofii średniowiecznej. -Dionizego), po których filozofia świata starożytnego dotarła do średniowiecza ${ }^{2}$. Natomiast Stefan Swieżawski nazywa go drugim obok Augustyna, filarem średniowiecznej myśli zachodniej ${ }^{3}$, gdyż prace jego stanowią istotny wkład w rozwój ówczesnej filozofii i teologii. W niniejszym tekście chciałbym jednak

$1 \quad$ Problem z zaklasyfikowaniem do konkretnej epoki myślicieli żyjących w okresach ich przełomu wynika z przyjętego kryterium periodyzacji dziejów. Tę, która sytuuje Boecjusza w gronie myślicieli średniowiecznych, zaproponował między innymi Cellariusz (1638-1707), autor podręcznika historii powszechnej (Historia universalis, 1688), popularyzującego podział dziejów na okres starożytny, nowożytny i średniowieczny. Jako granice dla ostatniej z wymienionych epok przyjął on wstąpienie na tron Konstantyna Wielkiego w 306 roku oraz zdobycie Konstantynopola przez Turków w 1453 roku. Zob. W. Seńko, Jak rozumieć filozofię średniowieczną, Kęty 2001, s. 5. Jeżeli jednak uznamy, że koniec starożytnej filozofii pogańskiej wyznacza rok 529 i edykt Justyniana, to wówczas Boecjusza zaliczyć trzeba w poczet filozofów antycznych, z czym koresponduje chociażby określanie go mianem „ostatniego Rzymianina”. Zob. G. Reale, Historia filozofii starożytnej, t. 4, przeł. E. I. Zieliński, Lublin 1999, s. 688-689.

Zob. F. Copleston, Historia filozofii, t. 2, przeł. S. Zalewski, Warszawa 2004, s. 95.

Zob. S. Swieżawski, Dzieje europejskiej filozofii klasycznej, Warszawa-Wrocław 2000, s. 379. O wpływie Boecjusza na średniowiecze świadczy również opinia Agnieszki Kijewskiej, która zauważa, że cały wiek XII został określony jako „wiek Boecjański” (aetas Boethiana). Zob. A. Kijewska, Pomiędzy starożytnościq a średniowieczem: Boecjusz, [w:] Przewodnik po filozofii średniowiecznej. Od św. Augustyna do Joachima z Fiore, red. A. Kijewska, Kraków 2012, s. 59. 
zaakcentować nie tyle aspekt „doktrynalny” dorobku Boecjusza - co nie znaczy, że można go całkowicie pominąć - ile raczej kwestie „metafilozoficzne" obecne w De consolatione philosophiae ${ }^{4}$. Dzieło to kontynuuje bowiem pewne antyczne sposoby rozumienia filozofii ${ }^{5}$. Proponuję zatem skoncentrować się na tym, jak autor przedstawił owe wymiary i formy pojmowania „umiłowania mądrości”. Celem niniejszego artykułu jest więc próba ukazania - w kontekście omawianego dzieła - całego spektrum filozoficznego etosu, którego istota opiera się na kanwie filozofii jako określonego modelu życia. Właśnie w ten sposób ujęta natura filozofii sprawia, że może ona być dostępna człowiekowi wszędzie tam, gdzie pojawia się potrzeba troski o duszę - o należyty kształt ludzkiego życia na każdym jego etapie. To dlatego dynamika filozoficznego etosu

4 Prezentacja natury filozofii pozbawiona jest tutaj motywów religijnych. Ów brak Swieżawski tłumaczy tym, że dla autora De consolatione filozofia jest przede wszystkim oświeceniem rozumnego ducha przez mądrość. Zob. tenże, Dzieje europejskiej filozofii klasycznej, dz. cyt., s. 382. Koresponduje to również z poglądem, iż dla Boecjusza jedynym autorytetem w dziedzinie filozofii pozostaje rozum. Zob. W. Seńko, Jak rozumieć filozofię średniowieczną, dz. cyt., s. 110111. Natomiast Czesław Gładczuk dodaje, że omawiane dzieło analizuje podejmowaną problematykę „w wizji filozoficznej” i temu poziomowi metodologicznie i rzeczowo pozostaje wierny. Zob. C. Gładczuk, Boecjusza sztuka mądrości, „Studia Teologiczne”, 1985, t. 3, s. 244. Kijewska zauważa zaś, że już w X wieku zastanawiano się (Bowo z Corvey), dlaczego Boecjusz - pisząc De consolatio$n e$ - nie szukał pociechy w wierze. W XVIII wysunięto nawet hipotezę, że autor traktatów teologicznych i autor O pocieszeniu to dwie różne osoby (G. Arnold). Zob. A. Kijewska, Pomiędzy starożytnością a średniowieczem: Boecjusz, dz. cyt., s. 52.

5 Richard Heinzmann stwierdza, że całe wręcz dzieło Boecjusza wyrasta niemal wyłącznie z tradycji starożytnej i neoplatońskiej. Zob. tenże, Filozofia średniowiecza, przeł. P. Domański, Kęty 1999, s. 94. Warto przytoczyć tu słowa Boecjusza z jego komentarza do Arystotelesowskiej Hermeneutyki, w których zapowiada on, że - po przetłumaczeniu i skomentowaniu wszystkich dzieł Arystotelesa oraz dialogów Platona - postanawia wykazać zgodność ich poglądów w tym, co w filozofii największe. Jedną z inspiracji dla takiej tendencji unifikującej mogły być, zdaniem Mariana Kurdziałka, studia Boecjusza w Aleksandrii, która była stolicą harmonizowania poglądów Arystotelesa i Platona. Zob. M. Kurdziałek, Zachęta Boecjusza do jednania pogląów Arystotelesa i Platona oraz Boecjańskie i Augustyńskie wezwanie do łączenia wiary z rozumem, [w:] tenże, Średniowiecze w poszukiwaniu równowagi między arystotelizmem a platonizmem, Lublin 1996, s. 47. Por. A Kijewska, Boecjusz: życie i dzieło, [w:] Boecjusz, Traktaty teologiczne, przeł. A. Kijewska, R. Bielak, Kęty 2002, s. 22. Na temat kulturowych źródeł De consolatione zob. J. Siwecki, Zagadnienia filozoficzne konsolacji Boecjusza (cz. II), „Przegląd Filozoficzny” [dalej: PF], R. XXXV, 1932, z. 1-2, s. 87-95. 
objawia różnorodność swego „oblicza” zależnie od sytuacji i okoliczności, w jakich znalazł się Boecjusz. Jest mu bliska jako teoria i rozumowe poznanie, ale również jako praktyka i codzienna działalność; jako kontemplacja kosmicznej harmonii, ale też jako przejaw moralnego zaangażowania; jest motywem indywidualnej aktywności, a z drugiej strony społeczno-politycznego funkcjonowania. Staje się wreszcie obecna w sytuacjach życiowego powodzenia i jego tragizmu, w momentach rozpaczy, ale też pocieszenia ${ }^{6}$.

Warto zauważyć, że o ścisłej zależności tych wymiarów filozoficznego etosu zdaje się świadczyć fakt, iż ich prezentacja w dziele Boecjusza przybiera formę określonej chronologii zdarzeń. Najpierw bowiem obserwujemy realizację filozofii jako sposobu życia, następnie jego tragiczny finał, a wreszcie reakcję na ten tragizm w postaci filozoficznej terapii. Ta sekwencja wydarzeń stanie się również schematem dla argumentacyjnej struktury niniejszego tekstu. W pierwszej jego części zaprezentowana zostanie filozofia jako model życia, w którym poznanie i wiedza stają się receptą w obszarze indywidualnego postępowania i społeczno-politycznego zaangażowania. Wydaje się, że tylko przy takim rozumieniu filozofii można mówić o kolejnych dwóch aspektach „umiłowania mądrości”: najpierw „tragicznym”, a następnie „terapeutycznym”. Dlatego też w drugiej części tego artykułu przedstawiony zostanie dramat losów filozofia i paradoks atopiczności samej filozofii. Natomiast na tle szlachetności ideałów moralnej nieskazitelności, ukazany zostanie tragizm jej konfrontacji z bezwzględnością zła. Część trzecia

6 Kijewska jest autorką tekstu zatytułowanego: Filozofia Boecjusza - pomiędzy terapia a ćwiczeniem duchowym („Acta Mediaevalia”, 2002, t. 15, s. 45-59), w którym twierdzi, że w De consolatione Boecjusza wyraźnie widać przejście od terapii do duchowego ćwiczenia, skierowanego na metamorfozę osobowości. Zgadzając się z tezami obecnymi we wskazanej pracy, w swoim artykule chciałbym zaakcentować raczej specyfikę filozoficznego etosu, który poprzez określony sposób życia i jego tragiczny finał przyczynił się do konieczności zastosowania owej terapii. Przedmiotem mojej uwagi jest zatem nie tylko terapeutyczny wymiar filozofii - ten stanowiłby bowiem ostatni etap realizacji filozoficznego etosu - ale także jej rozumienie jako pewnego sposobu życia, który skutkuje dramatycznym finałem. Próbuję również wskazać, że dramat głównego bohatera przeradza się do pewnego stopnia w tragizm samej filozofii, w istotę której zdaje się być nieodłącznie wpisana cecha atopiczności. 
stanowić będzie analizę specyfiki „terapii” - czyli rozumienia filozofii jako „lekarstwa”, które istotę filozofii każe ostatecznie widzieć w indywidualnym doświadczeniu duchowej przemiany.

Motywem wprowadzającym w De consolatione Boecjusza, a także jego sytuacyjnym kontekstem jest życiowy dramat głównego bohatera ${ }^{7}$. Dlaczego jednak te osobiste wydarzenia mają związek z filozofią, stając się jednocześnie inspiracją do swoistego rozrachunku z pewną propozycją jej pojmowania? Otóż Boecjusz, pełniąc publiczną funkcję, postanowił żyć i działać w oparciu o te zasady i wskazania, które odnalazł właśnie w filozofii ${ }^{8}$. Jako inspirację dla takiej postawy życiowej wymienia Platona i jego trzy znamienne postulaty: rządy miłośników mądrości lub filozoficzne kształcenie aktualnych władców, następnie powinność przejęcia władzy wówczas, gdy istnieje obawa, że obejmą ją złoczyńcy, i wreszcie imperatyw troski o dobro wspólne $e^{9}$. Obserwujemy więc tutaj bardzo wyraźną deklarację „filozofowania zaangażowanego" w przestrzeni prywatnego życia, ale również w wymiarze polityczno-społecznym. Na czym jednak ten filozoficzny sposób życia miałby polegać? Życie filozofa to dla Boecjusza po prostu życie wzorowane na kosmicznym ładzie i harmonii ${ }^{10}$. To życie w sprawiedliwości i prawości

7 Na temat literackiej formy De consolatione jako prosimetrum zob. A. Kucz, Dyskurs $z$ Filozofia w "Consolatio Philosophiae” Boecjusza, Katowice 2005, s. 44-49. Por. uwagi Jerzego Siweckiego dotyczące rozumienia omawianego dzieła jako protreptyku, konsolacji i traktatu o życiu szczęśliwym. Zob. J. Siwecki, Zagadnienia filozoficzne konsolacji Boecjusza (cz. II), dz. cyt., s. 81-87.

Zob. Boecjusz, O pocieszeniu, jakie daje filozofia, przeł. W. Olszewski, Warszawa 1962, ks. I, 4 (dalsze cytaty wg tego wydania). Istnieje również nowsze tłumaczenie omawianego dzieła. Zob. Anicjusz Manliusz Sewerynus Boecjusz, O pocieszeniu, jakie daje filozofia, przeł. G. Kurylewicz, M. Antczak, Kęty 2006. Każde odwołanie do omawianego dzieła uzupełnione zostanie również odniesieniem do wydania łacińskiego: Anicii Manlii Severini Boethii, Philosophiae consolatio, Opera, pars I, edid L. Bieler, Corpus Christianorum Series Latina XCIV, Turnholti, Typographi Brepols Editores Pontificii MCMLVII. Odniesienie takie zawierać będzie numer księgi, rozdziału i sentencji (np. DeCons., I.4.7-27), podobnie sekcje wierszowane (np. DeCons., III.m11.1-16).

Zob. Platon, Państwo, 473 D-E, 499 B-D, 347 B-D, 342 A-343 A, przeł. W. Witwicki, Kęty 2001.

Zdaniem Siweckiego „etyka w «Consolatio» jest ściśle związana z kosmologią. Życie moralne winno być normowane prawami, jakie rządzą wszechświatem. Stąd «zadaniem filozofii jest wydobyć przyczyny ukrytych rzeczy i wytłumaczyć zasłonięte cieniem racje»" (J. Siwecki, Zagadnienia filozoficzne konsolacji Boecjusza, PF, R. XXXIV, 1931, z. 2-3, s. 114). 
postępowania, które swój przykład znajduje w uporządkowanych strukturach świata ${ }^{11}$. To również życie oparte na praktykowaniu szlachetnych obyczajów, a także na nieczynieniu jakiegokolwiek zła i niegodziwości ${ }^{12}$. Filozoficzny sposób życia polega więc na tym, że filozof najpierw dba o dobro i piękno własnej duszy (i w tym właśnie sensie troszczy się o nią), a następnie, w sposób analogiczny do kondycji własnej duszy, działa. A zatem filozofia, której zasady Boecjusz postanowił urzeczywistnić, to filozofia bardzo bliska codzienności konkretnego człowieka albo wręcz przeznaczona do tego, by po prostu żyć jej wskazaniami. To jednocześnie filozofia, która nie jest jedynie systemem górnolotnych maksym i sentencji, w szacie abstrakcyjnych formuł i elitarnej wzniosłości, pozostających jedynie na peryferiach ludzkiej egzystencji. Filozofia Boecjusza - „mistrzyni wszelkich cnót”"13 - wkracza w to życie w sposób bezpośredni, a jako wzorzec szlachetności i sprawiedliwości postępowania wypełnia swą treścią życie Boecjusza, przemieniając je na wzór proponowanych przez nią zasad.

Nie znaczy to jednocześnie, że Boecjusz nie przyznaje wartości filozofii jako pewnej formy wiedzy i poznania ${ }^{14}$. W jego przekonaniu nie ma żadnego konfliktu między pojmowaniem filozofii na kształt „wiedzy o rzeczach ludzkich i boskich” a traktowaniem jej jako pewnej recepty na indywidualny sposób życia oraz działalność w sferze publicznej ${ }^{15}$.

11 Zob. Boecjusz, O pocieszeniu..., ks. I, 4. (DeCons., I.4.7-14).

12 W rozmowie z Filozofią Boecjusz wymienia konkretne sytuacje życiowe, w których pozostał wierny ideałom prawości postępowania. Zob. tamże, ks. I, 4. (DeCons., I.4.28-149). Czesław Gładczuk przypisuje Boecjuszowi „bezkompromisową prawość”, „niezawisłość sumienia” i „obronę krzywdzonych”. Zob. tenże, Boecjusza sztuka mądrości, dz. cyt., s. 236-237.

13 Zob. Boecjusz, O pocieszeniu..., ks. I, 3. (DeCons., I.3.5-8).

14 Tomasz Tiuryn zwraca uwagę na rolę omawianego dzieła (zwłaszcza jego piątej księgi) w Boecjańskiej koncepcji uniwersaliów. Zob. tenże, Boecjusz i problem uniwersaliów, Wrocław 2009, s. 315-330. Znaczenie księgi piątej, jako wykładni Boecjańskiej koncepcji zdolności poznawczych człowieka, podkreśla Kurdziałek. Zob. tenże, Odbiór Boecjuszowej „Zachęty” w XII wieku, [w:] tenże, Średniowiecze w poszukiwaniu równowagi..., dz. cyt., s. 75-76.

15 Kijewska zauważa, że w omawianym dziele Boecjusza Filozofia przedstawiona jest zgodnie z jej hellenistyczną definicją jako wiedza o rzeczach ludzkich oraz boskich. Dzieli się na część teoretyczną i praktyczną. „W «Komentarzu do Izagogi» Porfiriusza Boecjusz powie, że są to dwie «species» filozofii". Zob. A Kijewska, Boecjusz: życie i dzieło, dz. cyt., s. 26. Por. W. Seńko, Jak 
Filozoficzna droga mądrości i zgłębiania tajemnic natury zdaje się więc raczej iść $\mathrm{w}$ parze z praktykowaniem cnót oraz prawością moralnego postępowania ${ }^{16}$. Ta dynamika umiłowania mądrości, która spaja w swej istocie element rozumowego poznania (logosu) i określonego sposobu życia (ethosu), teorii i praktyki, jak również symbolika związana z samym wydarzeniem pojawienia się upersonifikowanej Filozofii ${ }^{17}$, wpisuje się w „paradygmat” rozumienia „umiłowania mądrości” jako pewnego sposobu życia ${ }^{18}$, konkretyzującego się w trosce o dobro duszy ( $p$ sychagogia ${ }^{19}$ ). Podkreślmy to jednak raz jeszcze: zdaniem Boecjusza nie istnieje żadna sprzeczność między filozofią jako wiedzą o „ostatecznych prawach bytu” a jej praktyką, czyli konkretnym sposobem życia. Należy raczej powiedzieć, że filozoficzne życie czerpie wzorce właśnie z uprzedniego poznania kosmicznego ładu i harmonii. To na ich podobieństwo filozof zaczyna również kształtować swą duszę. Filozoficzne „praktykowanie moralnej doskonałości” jest więc jakby drugą odsłoną pełni umiłowania mądrości. Ale nie tylko kosmiczny porządek staje się wzorcem

rozumieć filozofię średniowieczną, dz. cyt., s. 97. Ważna jest również opinia Jerzego Gułkowskiego, w której stwierdza on, że wyodrębnienia siedmiu sztuk wyzwolonych dokonał Boecjusz w ramach tego działu filozofii teoretycznej, którego domeną są naturalia - ciała naturalne stanowiące przedmiot fizjologii odpowiadającej Arystotelesowskiej fizyce. Natomiast filozofia praktyczna obejmowałaby wg Boecjusza wiedzę o nabywaniu cnót i właściwym człowiekowi postępowaniu, wiedzę o rozumnym i cnotliwym kierowaniu państwem i wreszcie wiedzę o kierowaniu rodziną. Zob. J. Gułkowski, Boecjusz - ostatni rzymski filozof i pierwszy scholastyk, „Meander”, 1975, t. 30, z. 1112, s. 459.

16 Komentując De consolatione, Juliusz Domański stwierdza, że upersonifikowana Filozofia, która pociesza Boecjusza, jest mądrością raczej moralną aniżeli spekulatywną. Zob. J. Domański, Metamorfozy pojęcia filozofii, przeł. Z. Mroczkowska, M. Bujko, Warszawa 1996, s. 27.

17 O symbolice personifikacji filozoficznej mądrości pod postacią kobiety zob. A. Kijewska, Filozof i jego muzy. Antropologia Boecjusza - jej źródła i recepcja, Kęty 2011, s. 309-316; por. A. Kucz, Dyskurs z Filozofia..., dz. cyt., s. 63-68.

18 Na temat rozumienia filozofii antycznej jako sposobu życia zob. J. Domański, Metamorfozy pojęcia filozofii, dz. cyt.; tenże, „Scholastyczne” i „humanistyczne” pojęcie filozofii, Kęty 2005; P. Hadot, Czym jest filozofia starożytna?, przeł. P. Domański, Warszawa 2000; tenże, Filozofia jako ćwiczenie duchowe, przeł. P. Domański, Warszawa 2003; P. Paczkowski, Filozoficzne modele życia w klasycznym antyku (IV w. p.n.e.), Rzeszów 2005.

19 Por. H. G. Liddell, R. Scott, H. S. Jones (et al.), A Greek-English lexicon, rev. ed., Oxford 1996, s. 2026, sub voce psychagogeo. 
dla przemiany duszy. Poznanie fundamentalnych praw świata, reguł odwiecznej sprawiedliwości, natury prawdziwego szczęścia, rzeczywistego statusu zła, ludzkiej wolności, a wreszcie roli opatrzności sprawia, że zmienia się również świadomość filozofa. Posiadając tę wiedzę, już inaczej patrzy on na to, co przynosi los, a zarazem inaczej też żyje. Świat nie jest już miejscem tryumfu zła, gdyż w prawie opatrzności cnota zyskuje należną jej wartość. Bezład i przypadkowość stają się w rzeczywistości tylko pozorem, który ginie w obliczu ostatecznego sensu wszystkich życiowych wydarzeń. To dlatego - zyskując jakby tę „boską” optykę spojrzenia - filozof staje niejako „obok” świata, a w efekcie uzyskanego wglądu w odwieczne prawa bytu okazuje się być niejako „innym człowiekiem". Zatem filozofia gruntownie zmienia człowieka na tyle, na ile on sam jest w stanie wytrwać $\mathrm{w}$ takiej perspektywie widzenia świata.

Wydaje się, iż tylko w taki właśnie sposób rozumiana filozofia - jako recepta na życie - mogła stać się adresatem żalu i rozgoryczenia spowodowanego dramatycznymi wydarzeniami, których doświadczył Boecjusz. „Czyż taki pożytek odnosimy z tego, że cię słuchamy? Czyż nasz sposób życia na to zasłużył?" - pyta Filozofię Boecjusz? I natychmiast odpowiada: „Jaki wynik spotkał naszą niewinność, widzisz: w miejsce nagrody za prawdziwą cnotę odnoszę karę za zmyśloną zbrodnię" ${ }^{\prime 20}$. Warto zauważyć tutaj pewną konsekwencję: otóż, skala pretensji obrazuje $\mathrm{w}$ istocie skalę filozoficznego zaangażowania, a jednocześnie rozczarowania jego dramatycznym wynikiem. Im bowiem głębiej umiłowanie mądrości przeniknęło codzienne życie Boecjusza, tym bardziej tragiczny jego finał potęguje żal i gorycz rozczarowania. Trudno dziwić się tym pretensjom, skoro filozofia miała stać się receptą na życie, a pośrednio okazała się być źródłem jego dramatu. Rozczarowanie takim wynikiem filozoficznego zaangażowania jest tym większe, im bardziej przypisywać się będzie filozofii miano dyscypliny ekskluzywnej i szlachetnej, bo sięgającej przecież przestrzeni „boskiej wiedzy” i najgłębszych „tajemnic natury”. Doświadczenie, które stało się udziałem Boecjusza, nie jest w tej materii precedensem. Wystarczy tylko wspomnieć 
o oskarżeniu Anaksagorasa, procesie Sokratesa, jak również Platońskiej aktywności politycznej na Sycylii, aby tragedię Boecjusza wpisać $\mathrm{w}$ pewien nurt filozofii zaangażowanej społecznie i politycznie. Jednakże tragizm sytuacji Boecjusza wyraża coś więcej. Pełni on raczej funkcję fundamentalnego pytania o to, czy oparte na filozofii zaangażowanie zawsze musi kończyć się dramatem fiaska, fałszywych oskarżeń i wyroków śmierci? Dla Boecjusza trudna do zaakceptowania jest kolizja prawości filozoficznego postępowania z tryumfem celowo podejmowanego zła. Trzeba jednak zauważyć, że nie wini on filozofii za obecność zła na świecie. Pod jej adresem kieruje raczej zarzut pewnego rodzaju bierności i nieskuteczności w konfrontacji z owym złem. Pretensja Boecjusza dotyczy tego, że prawda sama $\mathrm{z}$ siebie nie jest w stanie zwyciężyć, a dobro okazuje się być słabsze od zła, przed którym nawet filozofia w imię wzniosłości swych zasad nie potrafiła się obronić. Dlatego też dramat Boecjusza staje się do pewnego stopnia również dramatem samej filozofii. Zwracając się do niej, w pewnym momencie stwierdza on, że „wiarygodność popełnienia tak wielkiej zbrodni wywodzą z ciebie i przez to samo uchodzić będę za wmieszanego w przestępstwo, że nakarmiony twoimi naukami jestem wprowadzony w twój sposób życia”21. W tym właśnie tkwi największy chyba tragizm filozofii, że - choć przysposobiona w szlachetność cnót - w obliczu zła okazuje się być bezsilna. Pretensje kierowane pod jej adresem wynikają poniekąd stąd, że to ona właśnie oferowała Boecjuszowi pewien pogląd na świat i prawa nim rządzące. Ale to postrzeganie świata przez pryzmat wartości cnotliwego życia przyniosło jedynie udrękę i niezawinione cierpienie. Obraz świata proponowany przez filozofię okazał się więc w jakimś stopniu obrazem nieprawdziwym, a filozoficzny sposób życia okazał się sposobem nieprzystającym do jego realiów. Może więc filozofia powinna właśnie poprzestać na sferze „boskiej wiedzy”, z piedestału której bezpieczniej jest tylko proponować określone zasady postępowania, które jednak lepiej - dla nich samych - aby pozostały poza możliwością ich urzeczywistnienia? Tragiczny przykład Sokratesa, Platona czy Boecjusza 
mógłby skłaniać ku takiej konkluzji. Cóż to jednak byłby za filozoficzny sposób życia i działania, który już z gruntu niejako nie pozwala na swe zrealizowanie? A może jest też tak, że filozofia daje się urzeczywistnić, ale tylko w intelektualnym „zaciszu” szkoły filozoficznej, gdyż w żaden inny sposób po prostu do życia nie przystaje, gdyż wzniosłość jej zasad stanowi zarazem o jej słabości w obszarze brutalnych i bezwzględnych niejednokrotnie polityczno-społecznych realiów?

Tragizm życiowych doświadczeń Boecjusza, jak również tragizm filozoficznego modelu życia, nie pozostaje jednak bez odpowiedzi. Upersonifikowana Filozofia ${ }^{22}$ przynosi lekarstwo, zaś jej ingerencja ma być właśnie na wskroś terapeutyczna. To drugi wymiar filozofii, również znajdujący swoje korzenie w tradycji Sokratejsko-Platońskiego umiłowania mądrości, które ma być terapią duszy ${ }^{23}$, podobnie jak filozof winien być jej lekarzem ${ }^{24}$. Dokładnie w tym kierunku postanawia działać Filozofia, gdy zwraca się do Boecjusza słowami: „najpierw więc pozwól mi kilku pytaniami dotknąć i zbadać twego ducha, bym zrozumiała, jakie metody zastosować dla twego leczenia"25. Na wstępie Filozofia podejmuje jednak ten wątek skargi Boecjusza, w którym utyskiwał on na niechlubny obraz filozoficznego życia, niezrozumienie jego istoty, a nawet

${ }^{22}$ W tej personifikacji Filozofii Swieżawski widzi podobieństwo do pojawienia się Diotymy w Platońskiej Uczcie. Zob. tenże, Dzieje europejskiej filozofii klasycznej, dz. cyt., s. 380-381.

23 Zob. Platon, Obrona Sokratesa, 29 E, 30 B. Por. tenże, Charmides, 153 D, 154 D-E, 156 E-157 C; tenże, Laches, 185 D-186 D, 190 B; tenże, Kriton, 47 C-48 A. Powyższe dzieła w: tenże, Dialogi, t. 1, przeł. W. Witwicki, Kęty 2005.

Natomiast o roli zdrowia duszy i konieczności jej leczenia zob. Platon, Hippiasz mniejszy, 372 E-373 A; tenże, Protagoras, 312 C, 313 A-C, 314 B; tenże, Gorgiasz, 464 A. Powyższe dzieła w: tenże, Dialogi, t. 1, przeł. W. Witwicki, Kęty 2005. Por. tenże, Państwo, 604 A-D. Por. tenże, Fajdros, 270 C; tenże, Sofista, 228 E. Powyższe dzieła w: tenże, Dialogi, t. 2, przeł. W. Witwicki, Kęty 2005.

24 Na temat terapeutycznego pojmowania filozofii oraz medycznych źródeł tego poglądu zob. W. Jaeger, Paideia. Formowanie człowieka greckiego, przeł. M. Plezia, H. Bednarek, Warszawa 2001, s. 515-561; P. Paczkowski, Filozoficzne modele życia $w$ klasycznym antyku (IV w. p.n.e.), dz. cyt., s. 37-42; B. Snell, Odkrycie ducha. Studia o greckich korzeniach europejskiego myślenia, przeł. A. Onysymow, Warszawa 2009, s. 211-214; O. Gigon, Główne problemy filozofii starożytnej, przeł. P. Domański, Warszawa 1996, 31-33; A. Krokiewicz, Zarys filozofii greckiej, Warszawa 2000, s. 240. Por. A. Bednarczyk, Medycyna i filozofia w starożytności, Warszawa 1999.

25 Boecjusz, O pocieszeniu..., ks. I, 6. (DeCons., I.6.1-3). 
fałszywe i krzywdzące jego oceny. Otóż Filozofia okazuje się być w pełni świadoma tego, że ludzie żyjący jej zasadami decydują się jednocześnie na brzemię - jak to określa - jej „znienawidzonego imienia”. Mało tego, fakt, iż nie od dziś mądrość wystawiona jest na niebezpieczeństwo, że od wieków staczała potyczki z bezmyślnością głupoty, że ludzie wychowani na jej obyczajach wydają się po prostu obcy, a wreszcie to, że - jak sama powiada - „głównym naszym zadaniem jest nie podobać się najgorszym"26, to wszystko ugruntowuje jeszcze bardziej samoświadomość tragiczności jej własnego wizerunku. Czy to mogło w jakiś sposób pomóc Boecjuszowi? Zapewne miało się przyczynić do zauważenia przez niego pewnej dramatycznej prawidłowości w sposobie oceny filozofii przez powszechną opinię. Uwagi poczynione przez Filozofię co do negatywnego odbioru jej istoty i znaczenia stanowią wyraz pewnej filozoficznej samoświadomości. I jak widać, musi ona stać się udziałem każdego, kto decyduje się drogę umiłowania mądrości uczynić treścią swego życia ${ }^{27}$. Upersonifikowana Filozofia próbuje więc pokazać, że ryzyko tragicznego finału filozoficznego zaangażowania wpisane jest jakby w istotę jej etosu, a Boecjusz nie doświadczył w zasadzie niczego „nadzwyczajnego”. Spotkało go raczej to, co jest nieodłącznie włączone w naturę filozofii: niezrozumienie, konflikt i tragiczna konfrontacja ze „światem”.

Po tym swoistym preludium filozoficznej samoidentyfikacji rozpoczyna się właściwa droga terapii ${ }^{28}$. Sedno terapii dotyczy głębi duszy Boecjusza, w której kryje się konkretny sposób widzenia świata i właściwej oceny obserwowanych wydarzeń. Filozofia ponownie więc sięga tam, gdzie raz już usytuowała swe zasady ${ }^{29}$. To znamienne, że jej terapeutyczna ingerencja nie aspiruje do tego, by w pewien sposób „uzdrowič

26 Tamże, ks. I, 3. (DeCons., I.3.32-34).

27 Domański zauważa, że ta kontestacja ludzi złych stanowi jakby zadanie filozofii nie tylko istotne, ale wręcz najważniejsze. Zob. tenże, „Scholastyczne” $i$ „humanistyczne” pojęcie filozofii, dz. cyt., s. 95.

28 Na temat symboliki i interpretacji poszczególnych etapów pocieszenia zob. A Kijewska, Boecjusz, Kraków 2011, s. 65-98.

29 Heizmann zauważa, że całe dzieło Boecjusza jest pewną doktryną duszy. Zob. tenże, Filozofia średniowiecza, dz. cyt., s. 93-97. 
chociażby sam Los i Fortunę, na stałe wykorzeniając zło. Nie chodzi jej też o zmianę zasad ludzkiego działania i zdeterminowanie go jedyną możliwością wyboru dobra. Sednem filozoficznej terapii jest raczej zmiana ludzkiego zapatrywania na cały przebieg życiowych wydarzeń $^{30}$. Dlatego też Filozofia diagnozuje najpierw u Boecjusza „wspólną wszystkim zawiedzionym umysłom chorobę śpiączki”31. Iskrę nadziei na wyleczenie dostrzega Filozofia w wierze Boecjusza w rządy boskiego rozumu nad światem ${ }^{32}$. Specyfika terapii, jakiej doświadcza Boecjusz, polega więc na tym, że dokonuje się ona na płaszczyźnie - można by rzec - „teoretycznej”. A zatem droga racjonalnej argumentacji nie zostaje zapoznana w nurcie filozoficznego sposobu życia. Raczej w tym sposobie aplikowania filozoficznego lekarstwa na nowo potwierdzony zostaje wzajemny związek obu aspektów Mądrości. W tytułowym pocieszeniu Filozofia usiłuje pokazać, że problem leży niejako „po stronie Boecjusza”, gdyż przyczyny nieszczęść znajdują się w żywionych przez niego fałszywych przekonaniach. Filozofia powiada bowiem, iż „taką jest natura umysłu, że ile razy odrzuca prawdziwe zapatrywania, tyle razy nasiąka fałszywymi, a z nich zrodzona mgłą wewnętrznego zamętu zaciemnia należyte poznanie" 33 .

Należy zwrócić uwagę na dwa elementy filozoficznego pocieszenia. Po pierwsze, filozofia nie ma bezpośrednio ingerować w odwieczne prawa rządzące światem, ale ma wskazać sens tego, co na pozór jest go zupełnie pozbawione. Po drugie, domeną filozofii jest przestrzeń ludzkiego ducha, sfera myśli podatna na racjonalne pouczenie ${ }^{34}$. W tym właśnie zakresie filozofia ukazuje swą największą siłę, gdy drogą logicznej

30 „Dlaczegóż więc, ludzie śmiertelni, szukacie szczęścia poza sobą, skoro je macie w sobie? Błąd i niewiedza was mącą" (Boecjusz, O pocieszeniu..., ks. II, 4. [DeCons., II.4.63-64]).

Tamże, ks. I, 2. (DeCons., I.2.7-9).

O roli „przeznaczenia” i „Opatrzności” w De consolatione Boecjusza zob. E. Gilson, Duch filozofii średniowiecznej, tłum. J. Rybałt, Warszawa 1958, s. 340-341. Na temat „Opatrzności” por. C. Gładczuk, Boecjusza sztuka mądrości, dz. cyt., s. 241-242.

33 Boecjusz, O pocieszeniu..., ks. I, 6. (DeCons., I.6.48-54).

34 Kijewska zauważa, że dialog między Filozofią a więźniem to rodzaj dialogu wewnętrznego. Do pieśni dziewiątej to Filozofia była lekarką i pocieszycielką. Natomiast od tego momentu konsolacja ma być samo-konsolacją. Zob. taż, Filozof i jego muzy..., dz. cyt., s. 318. 
argumentacji zdolna jest przemienić ludzkie widzenie świata, a w jego konsekwencji - całe życie. Czy może bowiem przynieść pouczenie natury innej niż ta, która określa jej najgłębszą istotę? Skoro filozofia jest Mądrością, to oferuje pewną mądrość, zaś sugestywność jej pouczenia jest sugestywnością na wskroś racjonalną. Przykład Boecjusza świadczy o tym, że filozofia zdolna jest jednak uformować ludzkiego ducha, wpłynąć na niego „wiarygodnymi argumentami” i „wnioskowaniem”35, a jednocześnie przynieść mu pocieszenie i uleczenie. Co więcej, filozofia staje się również przewodnikiem w kwestii ludzkiego szczęścia, demaskując jego pozory i jednocześnie wskazując, gdzie szukać prawdy jego oblicza ${ }^{36}$. Terapia dokonująca się w przestrzeniach ludzkiego ducha ma jeszcze tę zaletę, że przypomina - według wskazań samego Boecjusza - Platońską anamnezę $e^{37}$. Symbolika tego porównania mogłaby oznaczać, że dotychczasowa rola filozofii sprowadzałaby się do pełnienia przez nią jedynie funkcji pośredniczącej, pozostawiając w gruncie rzeczy duszę człowieka sam na sam z odwiecznymi przyczynami i prawami świata ${ }^{38}$. Jak zauważa przecież sam Boecjusz, filozofia ich nie ustanawia, ona je tylko bada i odsłania dla tych, którzy otwarci są na jej pośrednictwo ${ }^{39}$. Anamnetyczna analogia jest również o tyle słuszna, że filozoficzne pocieszenie opiera się na wskazaniach i pouczeniach, które Boecjuszowi były już znane. Nie stanowią więc żadnego novum, zostały jedynie „przyćmione” przez fałszywe przekonania. Filozoficzna

${ }_{35}$ Zob. Boecjusz, O pocieszeniu..., ks. III, 12; por. ks. IV, 1. (DeCons., III.12.10-96; IV.1.1-33).

Zdaniem Kijewskiej pod koniec księgi III daje się zaobserwować wyraźna zmiana kierunku rozważań. Od tego bowiem momentu nie chodzi już wyłącznie o ukazanie natury prawdziwego szczęścia, ale również o wskazanie drogi zbawienia - drogi osiągnięcia podobieństwa do boga. Zob. taż, Filozofia Boecjusza..., dz. cyt., s. 56.

${ }_{37}$ Zob. Boecjusz, O pocieszeniu..., ks. III, XI. (DeCons., III.m11.1-16). „Nie powiedziałaś mi rzeczy, które by mi były poprzednio z gruntu nie znane” (tamże, ks. IV, 1. [DeCons., IV.1.48]).

38 Odwołanie do anamnezy obecne jest nie tylko w koncepcji poznania Boecjusza, ale również w ramach problematyki szczęścia. Zob. J. Siwecki, Zagadnienia filozoficzne konsolacji Boecjusza, dz. cyt., s. 108, 110-111.

39 Zob. Boecjusz, O pocieszeniu..., ks. IV, 6. (DeCons., IV.6.165-187). 
konsolacja to w gruncie rzeczy argumentacja, która jednak nie zniewala, nie narzuca się, ale pozostaje propozycją w pełni zależną od ludzkiej wolności i zaangażowania.

Czy jednak każda próba podjęcia filozoficznego życia musi kończyć się dramatem i skazana jest jednocześnie na doświadczenie drugiego wymiaru filozoficznego etosu - jego aspektu terapeutycznego? Próba choćby zbliżenia się do rozwiązania tych problemów skłania w pierwszej kolejności do przyjrzenia się samej istocie filozofii. To znamienne „niepodobanie się najgorszym” i „odwieczne spieranie się z głupotą” sytuuje filozofię w paradygmacie swoistej atopiczności. Filozofia mówi wprost do Boecjusza, że jego ojczyzną jest „filozoficzne niebo” ${ }^{40}$. A zatem filozof jakby „nie jest stąd”, gdyż jego mądrość opiera się przecież na boskiej, dotyczącej ostatecznych zasad świata, wiedzy. Z gruntu więc zarezerwowanej tylko dla niektórych. Ten ekskluzywizm filozoficznej mądrości nie znajduje żadnego uznania w oczach powszechnej opinii, dla której jest to wiedza nieprzydatna i bezwartościowa. Analogicznie też deprecjonowany jest sposób życia oparty na wskazaniach filozofii. To dlatego właśnie w naturze filozofii leży sytuowanie się niejako „obok świata” i ciągła konfrontacja z jego niezrozumieniem ${ }^{41}$. Warto jednak pamiętać, że problemem filozofii nie jest jej „abstrakcyjno-teoretyczny” charakter. Ten nie jest w żaden sposób napiętnowany pod warunkiem, że filozoficzna pareneza pozostaje na płaszczyźnie moralnych sentencji i maksym. Problem pojawia się wówczas, gdy jej pouczenia stają się treścią codziennego życia. Na tej płaszczyźnie filozoficzna atopiczność widoczna jest tak wyraziście, jak nigdzie indziej, a głoszony przez nią ideał cnotliwego postępowania niesie ze sobą paradoksalne wręcz - w oczach ogółu - konsekwencje ${ }^{42}$. Proponowany przez filozofię sposób życia nie może być jednak paradoksalny sam w sobie, bo wówczas paradoksalne

40 Zob. tamże, ks. IV, I. (DeCons., IV.m1.25-26).

${ }^{41}$ Przywołując postać Anaksagorasa, Sokratesa, Zenona z Elei czy na przykład Seneki, Filozofia wyraźnie stwierdza, że „ich to właśnie wtrąciło w nieszczęście, że wychowani w moich obyczajach wydawali się dążnościom złych ludzi całkowicie obcy" (Boecjusz, O pocieszeniu..., I, 3. [DeCons., I.3.30-32]).

${ }^{42}$ Zob. tamże, ks. IV, 2-4. (DeCons., IV.2.65-128; IV.3.20-60; IV.4.1-63). 
byłoby nieczynienie zła i krzywdy, a także troska o prawość, szlachetność oraz nieskazitelność moralnego działania. Ten paradoks przeradza się w tragizm, ale tylko wtedy, gdy filozofia staje w obliczu bezkompromisowości zła. Jednakże na płaszczyźnie tej tragiczności filozoficzny etos się nie wyczerpuje. Odsłaniając swój terapeutyczny wymiar, filozofia pokazuje, że tragizm dobra i ideału cnotliwego postępowania jest tragizmem tylko wówczas, gdy patrzy się na niego z perspektywy „sądów ludzkich"43. W ich miejsce Filozofia proponuje Boecjuszowi własny punkt widzenia świata, w którym zwycięża dobro i sprawiedliwość, a zło, będąc de facto „ontologiczną" nicością, przyczynia się do największej szkody moralnej tego, kto je popełnia ${ }^{44}$. To dlatego graniczny moment bycia filozofem przenosi się w sferę duchowego wnętrza i osobistych przekonań. Albowiem filozofia nie zmieni świata, nie będzie ingerować w jego prawidłowości, bo nie taka jest jej rola; ale jest w stanie zmienić - jak w przypadku Boecjusza - ludzkie nań zapatrywania i sądy. Dylemat sprowadzający się do pytania, czy światem rządzi sprawiedliwy porządek, czy też ślepy i zły los, jest tak naprawdę dylematem rozgrywającym się w przestrzeniach ludzkiej duszy. Filozofia daje pewną propozycję jego rozwiązania, ale czy uda się je osiągnąć, to zależy już wyłącznie od ludzkiej konsekwencji i stopnia ugruntowania filozoficznych zasad.

Zatem w oczach filozofa, obserwowany tragizm i atopiczność sposobu jego życia pojawi się tylko i wyłącznie wtedy, gdy zapomni on o „boskiej” perspektywie filozoficznych przekonań - a więc, gdy spotyka go dokładnie to, co przydarzyło się Boecjuszowi. Stało się tak między innymi dlatego, że filozofia ugruntowana jest przecież na wiedzy i mądrości boskiej, a zatem dostępnej człowiekowi jedynie w stopniu ograniczonym lub nietrwałym. Nie leży w ludzkiej naturze całkowite i ostateczne jej posiadanie. Po drugie, filozoficzny sposób życia, jak widać, nie zniewala człowieka, nie opanowuje bez reszty, ale staje się „depozytem, który można utracić. Jednakże im większa jest wolność człowieka wobec 
reguł filozofii, tym większe znaczenie odgrywa konsekwentna ich realizacja. Wszystko zależy więc od siły ludzkiego ducha ${ }^{45}$. Po trzecie wreszcie, filozof tylko wtedy będzie miał poczucie tragizmu i atopiczności swojego sposobu życia, gdy będzie nieustannie konfrontował wybrany przez siebie los ze światem złudnych mniemań i moralnej nieprawości. Ten stan, jakby ciągłego balansowania między odmiennymi porządkami wartościowania, Filozofia charakteryzuje następującymi słowami: „wygląda to tak, jak gdybyś na zmianę patrzył na brudną ziemię i na niebo, wszystko inne na stronie pomijając: przez sam kierunek spojrzenia widziałbyś się raz w błocie, raz wśród gwiazd"46. Finał tej konfrontacji może stać się tragiczny wówczas, gdy w duszę wkradnie się zwątpienie i niepewność co do wartości ideału filozoficznego życia.

$\mathrm{Na}$ koniec można jeszcze zadać pytanie podsumowujące w pewien sposób powyższe uwagi, a mianowicie: jaki jest ostateczny cel filozofii? Gdyby przyjąć, że w zasadniczym wymiarze jest ona receptą na życie - drogą duchowej metamorfozy, to należy jeszcze zapytać, na czym miałaby polegać zmiana świadomości będąca jej zamierzonym następstwem? Wydaje się, że efektem filozofowania jest coś więcej aniżeli tylko spokój i pogoda ducha w obliczu tragicznych doświadczeń. Domeną filozofa staje się bowiem nowe spojrzenie na świat - zachodzi więc zasadnicza zmiana w systemie jego najgłębszych przekonań. Filozofia odsłania bowiem znajomość najistotniejszych prawidłowości funkcjonowania świata: tłumaczy zasadę szczęścia, rację istnienia zła czy też działanie opatrzności w perspektywie ludzkiej wolności. Ugruntowanie tej wiedzy decydująco wpływa na świadomość i postawę filozofa, który dzięki temu zyskuje wobec świata swoiste nastawienie aktywno-afirmatywne aniżeli tylko pasywno-zachowawcze, wobec domniemywanej przypadkowości i fatalności losu. Filozofia oferuje wiedzę, która jest w stanie zmienić człowieka, gdyż daje mu zupełnie nową perspektywę spojrzenia na otaczające go wydarzenia - pozwala mu dostrzec ich sens i znaczenie, umożliwia

45 Siwecki zauważa, że „ubóstwienie natury ludzkiej zdaje się być szczytowym punktem Boecjuszowej etyki” (tenże, Zagadnienia filozoficzne konsolacji Boecjusza, dz. cyt., s. 112).

46 Boecjusz, O pocieszeniu..., ks. IV, 4. (DeCons., VI.4.90-94). 
więc zrozumienie świata w najgłębszych prawidłowościach bytu. Dzięki temu człowiek staje wobec niego nie tyle obojętny w swej bezsilności, ile raczej spokojny, bo znający i rozumiejący jego fundamentalne prawa i najwyższe zasady. Tak rozumiana filozoficzna mądrość skutkuje zmianą świadomości i postawy człowieka. Co ważne, ta zmiana nie dokonuje się jedynie na płaszczyźnie terapeutycznej, a więc w ostatnim z wymienionych przejawów filozoficznego etosu. Należy raczej powiedzieć, że ma ona miejsce u samych jego źródeł, zaś filozoficzna terapia przywraca jedynie właściwą perspektywę widzenia świata.

Reasumując, dzieło Boecjusza pokazuje, że sugestywność pouczeń filozofii idzie w parze z siłą ludzkiego ducha, który jest władny je zaakceptować lub odrzucić. Efektem tego jest konkretny kształt świata: czy będzie on miejscem tryumfu zła i nieprawości, czy raczej sprawiedliwego porządku, to wszystko tak naprawdę zależy od ludzkiego nań spojrzenia. Jednakże w gestii człowieka leży również uczynienie siebie i swej duszy na wzór, jaki proponuje filozofia, która zwraca się do Boecjusza słowami: „W waszym bowiem ręku leży, jaki los sobie zechcecie stworzyć" ${ }^{47}$. Boecjusz staje się tym samym kontynuatorem antycznego ideału cnotliwego postępowania, którego wartość leży w samym jego praktykowaniu $^{48}$. Droga filozofii to droga cnotliwego życia, które potrzebuje tak wstępnych pouczeń, jak i chwilowego pocieszenia, które może przerodzić się $\mathrm{w}$ dramat zwątpienia lub sukces spokojnego, nawet wobec zawirowań losu, ducha. I w ten właśnie sposób ujawnia się przestrzeń dla dynamiki całego filozoficznego etosu, który - jeśli spróbować go urzeczywistnić - ukazuje różnorodność swego oblicza: od teorii po praktykę, od tragedii po pocieszenie, wreszcie od życia po śmierć. Można wręcz powiedzieć, że gdzie znajduje się człowiek w różnych momentach swej egzystencji, tam znajduje się też filozofia. Po wtóre, wartość urzeczywistnienia ideału tego filozoficznego etosu mierzona jest

47 Tamże, ks. IV, 7. (DeCons., IV.7.46-47).

48 „Jeśli ducha swego ukształcisz wedle wzorów lepszych, nie potrzeba, aby ci sędzia przyznawał nagrodę. [...] A jeśli skłonności swoje skierowałeś do rzeczy gorszych, nie szukaj poza sobą mściciela, boś sam siebie strącił do rzędu gorszych” (tamże, ks. IV, 4. [DeCons., VI.4.88-94]). 
trudem jego osiągnięcia i stopniem jego powszechności. Natomiast skala niezrozumienia owego etosu, w połączeniu z karykaturalnym jego wyobrażeniem dobitnie pokazuje tylko, że „ojczyzną” filozofa jest „inny świat”: Idei, Cnoty, Dobra czy też świat człowieka etycznie wysoko stojącego ${ }^{49}$. Mimo iż wymienione pojęcia odnoszą się do diametralnie czasem odmiennych koncepcji i sposobów ich rozumienia, to celem ich zestawienia jest właśnie wyrażenie zasadniczej atopiczności i intelektualno-moralnej ekskluzywności filozofa na tle powszechnie obowiązujących zasad. Realizacja wskazań Mądrości zależna jest tylko i wyłącznie od tego, kto decyduje się wstąpić na jej drogę i nikt nie wyręczy go w totalności filozoficznego zaangażowania. Filozofia może jedynie zachęcać słowami na wzór tych, które skierowała do Boecjusza: „idźcie więc, dzielni, gdzie na stromej drodze przykład wielki was wiedzie! Czemuż leniwi wycofujecie się $\mathrm{z}$ walki? Kto ziemię pokona, ten zdobędzie gwiazdy!"50.

\section{Bibliografia}

1. Boecjusz, O pocieszeniu, jakie daje filozofia, tłum. W. Olszewski, Warszawa 1962.

2. Copleston F., Historia filozofii, t. 2, tłum. S. Zalewski, Warszawa 2004. Domański J., Metamorfozy pojęcia filozofii, tłum. Z. Mroczkowska, M. Bujko, Warszawa 1996.

3. Kijewska A., Boecjusz: życie i dzieło, [w:] Boecjusz, Traktaty teologiczne, tłum. A. Kijewska, R. Bielak, Kęty 2002.

49 Oczywiście trudno jest postawić znak równości między wymienionymi pojęciami lub też wspólnie zaklasyfikować je do tego samego „innego świata”. Na przykład świat Idei to świat „inny” ontycznie, zaś stoicki ideał cnoty to świat moralnych postulatów wobec jednostki, a jego „inność” może być pojmowana jako „odmienność od powszechnie praktykowanego”. Każda z nich określała w sposób istotny specyfikę charakterystycznego dla siebie modelu filozofii, a jednocześnie wyrażała właśnie zasadniczą odmienność cechującą filozofię względem ówczesnego sposobu myślenia i działania.

50 Boecjusz, O pocieszeniu..., ks. IV, VII. (DeCons., VI.m7.32-35). 
4. Kijewska A., Filozofia Boecjusza - pomiędzy terapia a ćwiczeniem duchowym, „Acta Mediaevalia”, 2002, t. 15, s. 45-59.

5. Kijewska A., Pomiędzy starożytnościa a średniowieczem: Boecjusz, [w:] Przewodnik po filozofi średniowiecznej. Od św. Augustyna do Joachima z Fiore, red. A. Kijewska, Kraków 2012.

6. Kucz A., Dyskurs $z$ Filozofia w „Consolatio Philosophiae” Boecjusza, Katowice 2005.

7. Liddell H. G., Scott R., Jones H. S. i in., A Greek-English Lexicon, wyd. popr., Oxford 1996.

8. Platon, Państwo, tłum. W. Witwicki, Kęty 2001.

9. Reale G., Historia filozofii starożytnej, t. 4, tłum. E. I. Zieliński, Lublin 1999.

10. Świeżawski S., Dzieje europejskiej filozofii klasycznej, Warszawa -Wrocław 2000. 